\title{
Salbutamol and ipratropium in acute asthma
}

\author{
R J RAYNER, P H T CARTLIDGE, AND C J UPTON \\ City Hospital, Nottingham
}

SUMmaRY Thirty seven children with acute asthma were given nebulised ipratropium or placebo 30 minutes after their first dose of salbutamol and eight hourly thereafter. There were no significant differences between the two groups in clinical scores, peak expiratory flow rates, length of stay in hospital, or the need for oral steroids.

Ipratropium bromide is an effective bronchodilator in children, ${ }^{1-3}$ but its place in the management of acute asthma is not clear. Storr and Lenney were unable to show any benefit when children were given a mixture of nebulised salbutamol and ipratropium compared with salbutamol alone. ${ }^{4}$ The two drugs in sequence, however, have been reported to produce greater bronchodilatation than either used separately. ${ }^{56} \mathrm{We}$ wanted to establish whether giving nebulised ipratropium after salbutamol conferred any therapeutic benefit over salbutamol alone.

\section{Patients and methods}

Twenty eight boys and 12 girls, mean age 6.5 years (range 2-15), who were admitted to this hospital with acute asthma were randomly allocated to two groups in a double blind trial. All had received $\beta_{2}$ receptor agonists at home, but none had been given ipratropium or oral steroids. Both groups received nebulised salbutamol $(2.5 \mathrm{mg}$, or $5 \mathrm{mg}$ for those over 6 years old) on admission and four hourly thereafter. Thirty minutes after the first dose of salbutamol, and eight hourly thereafter, they received either nebulised placebo ( $3 \mathrm{ml}$ physiological saline) or ipratropium ( $250 \mu \mathrm{g}$ in $2 \mathrm{ml}$ physiological saline). Steroids were given as usual if good relief was not obtained.

Assessments were made by one of us on admission, immediately before and 45 minutes after the first administration of the trial drug, and the next morning (12-24 hours later). Thirty one of the children were assessed by the same person (RJR). Pulse, respiratory rate, and, when possible, peak expiratory flow rate were measured. A clinical score was given, based on clinical examination, activity, and speech, the worst possible score being 25 . The time taken to achieve $80 \%$ of the expected peak flow rate, or to be considered fit for discharge, was recorded.

The study was approved by the hospital ethical committee, and written consent was obtained from the parents.

The results were analysed with Student's $t$ test. We calculated that a difference of more than 3 in clinical score, or $15 \%$ of the expected peak expiratory flow rate, between the two groups would be significant $(\mathrm{p}<0 \cdot 05)$.

\section{Results}

Two children failed to comply with the nebuliser treatment and one required intravenous treatment immediately after being given salbutamol, leaving 18 in the control group and 19 in the treatment group. The groups were closely matched for age and sex distribution, mean clinical scores, and peak flow rates on admission. Fourteen in the control group and eight in the treatment group were taking prophylactic drugs. Seven in the control group and 10 in the treatment group were using a nebuliser at home.

There was a significant response to salbutamol in both groups (Student's $t$ test, $\mathrm{p}<0 \cdot 001$ ), but there were no significant differences between the two groups in mean clinical score or peak expiratory flow rate after the first dose of the trial drug, or the next morning (Tables 1 and 2).

Table 1 Mean (SEM) clinical scores

\begin{tabular}{lcc}
\hline & $\begin{array}{l}\text { Control group } \\
(n=18)\end{array}$ & $\begin{array}{l}\text { Treatment group } \\
(n=19)\end{array}$ \\
\hline On admission & $12 \cdot 2(0 \cdot 8)$ & $12 \cdot 7(0 \cdot 8)$ \\
After salbutamol & $9 \cdot 1(0 \cdot 8)$ & $8 \cdot 6(0 \cdot 9)$ \\
After trial drug & $7 \cdot 6(0 \cdot 7)$ & $6 \cdot 6(0 \cdot 7)$ \\
Next morning & $3.9(0 \cdot 3)$ & $4 \cdot 6(0 \cdot 7)$ \\
\hline
\end{tabular}

Table 2 Mean (SEM) peak expiratory flow rates as percentages of expected values

\begin{tabular}{lll}
\hline & $\begin{array}{l}\text { Control group } \\
(n=12)\end{array}$ & $\begin{array}{l}\text { Treatment group } \\
(n=8)\end{array}$ \\
\hline On admission & $36 \cdot 9(2 \cdot 5)$ & $32 \cdot 2(2 \cdot 6)$ \\
After salbutamol & $51 \cdot 0(4 \cdot 4)$ & $55 \cdot 4(7 \cdot 0)$ \\
After trial drug & $56 \cdot 6(4 \cdot 8)$ & $57 \cdot 4(9 \cdot 0)$ \\
Next morning & $72 \cdot 0(4 \cdot 6)$ & $70 \cdot 4(6 \cdot 5)$ \\
\hline
\end{tabular}


The mean (SEM) length of stay in hospital was $23.9(3 \cdot 3)$ hours in the control group and $24 \cdot 5(2 \cdot 5)$ hours in the treatment group. Fourteen $(78 \%)$ of those in the control group and $14(74 \%)$ of those in the treatment group required oral steroids. Only one child (in the treatment group) required intravenous aminophylline, 15 hours after his admission and six hours after his second dose of ipratropium.

\section{Discussion}

Sixteen out of 37 children scored 13 or more on admission and 17 out of 19 children had a peak expiratory flow rate below $50 \%$ of the expected value. Nevertheless, we were unable to show significant benefit from the sequential use of nebulised ipratropium in addition to salbutamol. Therefore, although it may be valuable in individual children, the routine use of ipratropium in acute asthma cannot be recommended.

We thank Dr E J Hiller and Dr D A Curnock for allowing us to study their patients, the pharmacy department at the City Hospital for preparing the solutions, and the nursing staff of Papplewick Ward.

\section{References}

1 Mann NP, Hiller EJ. Ipratropium bromide in children with asthma. Thorax 1982;37:72-4.

${ }^{2}$ Groggins RC, Milner AD, Stokes GM. Bronchodilator effects of clemastine, ipratropium bromide and salbutamol in preschool children with asthma. Arch Dis Child 1981;56:342-4.

${ }^{3}$ Davis A, Vickerson F, Worsley G, Mindorff C, Kazim F, Levison $\mathrm{H}$. Determination of dose response relationship for nebulised ipratropium in asthmatic children. J Pediatr 1984;105: $1002-5$.

+ Storr J, Lenney W. Nebulised ipratropium and salbutamol in asthma. Arch Dis Child 1986;61:602-3.

5 Beck R, Robertson C, Galdes-Sebaldt M, Levison H. Combined salbutamol and ipratropium bromide by inhalation in the treatment of severe, acute asthma. J Pediatr 1985;107:605-8.

${ }^{6}$ Ward MJ, Fentem PH, Roderick-Smith WH, Davies D. Ipratropium bromide in acute asthma. $B r$ Med $J$ 1981;282: 598-600.

Correspondence to Dr R J Rayner, City Hospital, Hucknall Road, Nottingham NG5 1PB.

Received 19 February 1987

\title{
Prader-Willi syndrome in siblings, due to unbalanced translocation between chromosomes 15 and 22
}

\author{
F FERNANDEZ, C BERRY, AND D MUTTON
}

High Wycombe General Hospital and South East Thames Regional Genetics Centre, Guy's Hospital, London

SUMMARY In a family in which the father carried a balanced translocation between chromosomes 15 and 22 two of his children had Prader-Willi syndrome and an unbalanced chromosome complement, having lost the proximal bands from the long arm of chromosome 15 . His four other surviving children were normal but carried a balanced translocation.

\section{Case report}

The proband, who was 5 years old at the time of writing, was admitted to the special care baby unit when 3 days old with extreme hypotonia and feeding difficulties. He had been born to a consanguineous Asian couple and was the product of an uneventful pregnancy that had progressed to term; he had been delivered vaginally. Birth weight was $2020 \mathrm{~g}$, and he appeared otherwise normal apart from bilaterally undescended testes and a small scrotum. Tube feeding was necessary for two months. His development was delayed both physically and mentally: he walked at the age of $31 / 2$ and attended a special school for the educationally subnormal.

His next younger sibling had identical problems and was managed in the special care baby unit from the age of 5 days. He also was tube fed for two months. At over 1 year old he had a developmental age of 9 months and hypogonadism.

The family details are shown as a pedigree in Figure 1.

\section{Cytogenetics}

The proband was found to have a deletion of chromosome 15 during a study of children diagnosed as having Prader-Willi syndrome. ${ }^{1}$ In this study high resolution $G$ banding and Distamycin/DAPI fluorescence were used. ${ }^{2}$ This technique is valuable for defining the intense fluorescence that is characteristic of the short arms of chromosome 15.

There was no intense fluorescence on the short 